Apidologie, 1985, 16 (2), 99-108

\title{
PRELIMINARY INVESTIGATION ON THE DISTRIBUTION OF AFRICANIZED HONEY BEES IN ARGENTINA
}

\author{
A. DIETZ, R. KRELL and F.A. EISCHEN \\ Department of Entomology (1), University of Georgia, Athens, GA 30602, U.S.A.
}

\section{SUMMARY}

The preliminary results of a survey for Africanized honey bees conducted in 17 provinces of Argentina from January, 1983, to May, 1984, are presented. About 1300 colonies en 120 apiaries were sampled and evaluated with the defensive behavior test. Roadside samples and bees from feral colonies were collected at 392 sites. Morphometric analyses were used to determine the taxonomic status of the collected honey bee samples. Africanized honey bees were collected for the first time in Mendoza and at an altitude of $2000 \mathrm{~m}$ near Rodeo, San Juan. Additionally, Africanized honey bees were found in the province of Rio Negro $\left(39^{\circ} S\right)$, the southernmost location ever reported.

\section{INTRODUCTION}

The introduction of Apis mellifera adansonii, into Brazil in 1956 is well documented (Kerr, 1967, 1969 ; Goncalves, 1974 ; Michener, 1975 ; Dietz, 1982). Recently, Ruttner (1981) reported that the introduced bee was $A . m$. scutellata. In many popular publications this insect has been referred to as the Brazilian or killer bee. This misnomer was corrected by GonCALvES $(1974,1982)$ who recommended the term Africanized for the hybrid of imported African and European bees. The subsequent spread of Africanized bees into Argentina has not been clearly established. KEMPFF Mercado (1973) reported an annual westward migration rate of $150 \mathrm{~km}$ to Paraguay and Bolivia and the same rate for the southward movement. According to his estimate, Africanized bees reached the Santa Cruz district of Bolivia in 1968 after an invasion of Paraguay in 1964-1965. The occurrence of Africanized bees in northern Argentina (Misiones) during, or shortly prior to, this period is highly probable.

(1) This research was supported in part by Cooperative Agreement No. 25-21-RC 293-085 with the Bee Breeding and Stock Center Laboratory, U.S.D.A. Baton Rouge, LA. 
The distribution map presented by De SANTIS and CoRnejo (1968) shows the presence of Africanized bees in Formosa, Misiones and Corrientes in 1968. Africanized honey bees reached the northern border of Misiones in 1965 and by 1966 occupied about half of this province (De SANTIS and CORNEJo, 1968 ; TAYlor, 1977). Additional provinces (Formosa, Corrientes) were invaded in 1967 and probably most of Chaco and the northern part of Santiago del Estero and Santa Fe by 1968 . The southward spread of Africanized bees, is illustrated by Goncalves (1974) and TAYLOR (1977). The arrival of Africanized bees in the region of Cordoba by 1970 (KERR et al., 1982) is an indication that the bees migrated at a faster rate than the $120 \mathrm{~km}$ or $150 \mathrm{~km}$ reported respectively by TAYIOR (1977) and KempfF Mercado (1973).

KERR et al., (1982) reported that from the 30th to almost the 33rd parallel there is a resistance to the invasion of Africanized bees because of not oniy the cool and humid Argentine Pampas, but also due to the presence of a well developed beekeeping industry. They estimate that the honey bee population consists of about 30 percent aggressive colonies and 70 percent gentle, mostly Italian bees in this area. It has been suggested (KERR et al., 1982) that the inability of Africanized bees to become permanently established in areas south of the $33 \mathrm{rd}$ parallel is due to changes in ecological conditions. Consequently, the natural limit of the Africanized bee in Argentina has been placed between the $33^{\circ} \mathrm{S}$ and $34^{\circ} \mathrm{S}$ between the provinces of Entre Rios, Santa Fe, Cordoba and San Luis (KERR et al., 1982). These authors have also suggested that the appearance of Africanized bees south of this area are due to the commercial movement of bees and queens and not the result of natural swarming.

The distribution of Africanized honey bees in Argentina has not been studied in detail; nevertheless, environmental conditions appear to limit the southern spread of these bees. The identification of the conditions that limit honey bee colonization could be of considerable importance, not only to the U.S. beekeeping industry, but also to the general public.

The purpose of this investigation was to determine the distribution of Africanized bees in Argentina and to identify the transition zone of Africanization along a north-south gradient.

\section{MATERIALS AND METHODS}

The survey in Argentina was begun in January, 1983. During the next 5 month period, we tested the defensive behavior of at total of 600 colonies in 50 apiaries located in the following 9 provinces : Buenos Aires, Cordoba, Entre Rios, Formosa, Mendoza, Santa Fe, San Juan, 
Santiago del Estero and Tucuman. 570 honey bee samples were collected from these apiaries for supportive morphometric analysis. The second year survey was completed during the period of November, 1983, to May, 1984, and included an additional six provinces (Catamarca, La Rioja, La Pampa, Neuquen, Rio Negro and San Luis). During this period over 700 colonies were sampled and tested in about 70 apiaries. In addition, 392 roadside samples and bees from feral colonies were collected when possible every $50 \mathrm{~km}$ in the provinces of Chaco, Salta, Tucuman, Catamarca, La Rioja, San Juan, Mendoza, La Pampa and Rio Negro. Isolated collections of bees were also made in the provinces of Santiago del Estero, Entre Rios, Santa Fe, Cordoba, and Buenos Aires.

The field test of honey bee colony defensive behavior (Collins and Kubasek, 1982 ; Collins et al., 1982) was used to quantify aggressiveness in our distribution study. This field test consists of the following three types of stimuli (chemical, physical and visual-tactual) which are successively presented to the test colonies : a) a synthetic pheromone, b) a marble shot at the colony and c) two mechanically jiggled red suede targets $(5$ by $5 \mathrm{~cm})$. The presentation of each stimulus in a 30 second time interval sequence elicits four steps of defensive behavior : alerting, activating, attracting, and stinging. All observations were recorded and are presently being analyzed. Each colony was also inspected for parasites and diseases, their population of brood and bees cstimated, and a sample of 30 to 60 honey bees from brood combs collected for morphometric analysis. Dr. H. V. DALY, University of California, Berkeley, California identified morphometrically 40 samples of honey bees collected from colonies in the first year of the survey (see DALY and BALLING, 1978). The morphometric analysis of all other samples of field tested colonies were performed at the U.S.D.A. Bee Breeding and Stock Center Laboratory, Baton Rouge, Louisiana.

\section{RESULTS AND DISCUSSION}

The analysis of the data is incomplete, but based on some selected sampling and limited morphometric analysis, we found feral Africanized bees and managed colonies in the anticipated transition zone of Africanization between the $32^{\circ}$ and $34^{\circ}$ latitudes south of the equator. Surprisingly, we also collected a sample composed of $60 \%$ Africanized and $40 \%$ European bees in a colony near Cinco Saltos, Rio Negro. To our knowledge, the findings of Africanized bees near the $39^{\circ} \mathrm{S}$ is the most southern location ever recorded. The results presented in Fig. 1 represent roughly $6 \%$ of the total collected samples. We have also recorded for the first time the occurrence of Africanized bees in Mendoza and near Rodeo, San Juan.

During our survey, we encountered highly aggressive colonies of bees in the southern part of the province of Buenos Aires (see Figure 1 and Table 1). However, morphometric analysis indicates that these bees are clearly European even though they were as aggressive as the most aggressive Africanized bees encountered in Formosa and other areas. While the defensive behavior test is an excellent method of field identification of aggressive honey bee colonies, it must be supported by morphometric analysis for definitive taxonomic determinations. 


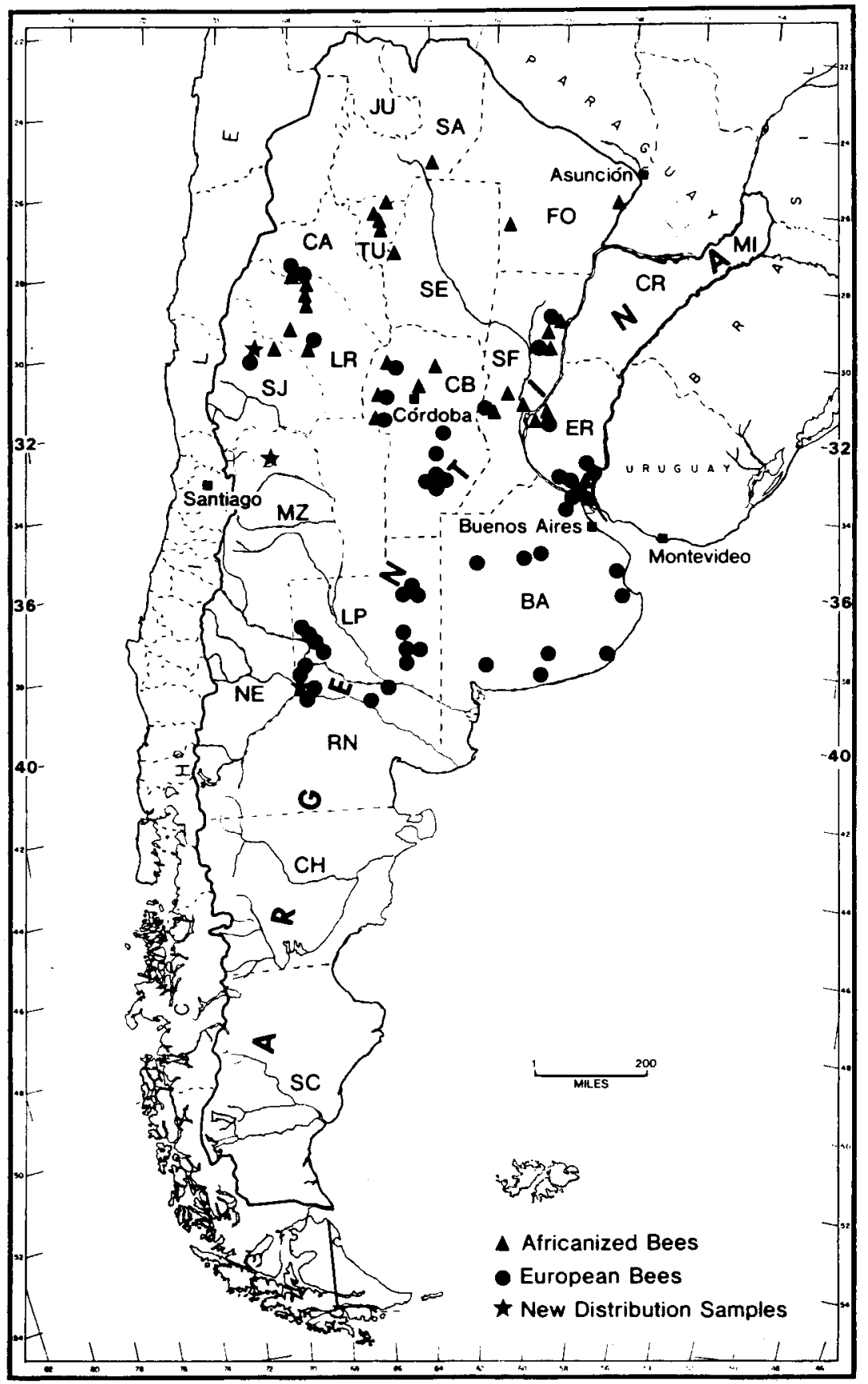

FrG. 1. - Preliminary survey of Africanized honey bees in Argentina 
TABL. 1. - Summary of field tested colonies and morphometrically analyzed honey bee samples collected in 17 provinces of Argentina (1983 and 1984)

\begin{tabular}{ll|r|r|r|r|r|r}
\hline \hline & \multicolumn{3}{|c|}{ No. of Collections } & \multicolumn{3}{c}{ Classification } \\
\cline { 2 - 7 } & Provinces & Apiaries & Colonies & $\begin{array}{r}\text { Feral \& } \\
\text { Roadsides }\end{array}$ & $\begin{array}{r}\text { Total } \\
\text { No. }\end{array}$ & $\begin{array}{c}\text { Africa- } \\
\text { nized }\end{array}$ & European \\
\hline BA & Buenos Aires & 19 & 211 & 72 & 21 & 0 & 21 \\
CA & Catamaca & 4 & 24 & 12 & 3 & 2 & 1 \\
CH & Chaco & 0 & 0 & 5 & 1 & 1 & 0 \\
CB & Cordoba & 17 & 188 & 114 & 13 & 4 & 9 \\
ER & Entre Rios & 11 & 128 & 3 & 14 & 5 & 9 \\
FO & Formosa & 4 & 39 & 0 & 1 & 1 & 0 \\
LP & La Pampa & 9 & 92 & 8 & 12 & 0 & 12 \\
LR & La Rioja & 2 & 18 & 3 & 6 & 5 & 1 \\
MZ & Mendoza & 10 & 112 & 17 & 1 & 1 & 0 \\
NE & Neuquen & 2 & 22 & 0 & 0 & 0 & 0 \\
RN & Rio Negro & 5 & 49 & 5 & 8 & 1 & 7 \\
SA & Salta & 0 & 0 & 2 & 1 & 1 & 0 \\
SJ & San Juan & 10 & 119 & 21 & 3 & 2 & 1 \\
SL & San Luis & 5 & 54 & 0 & 0 & 0 & 0 \\
SF & Santa Fe & 15 & 168 & 124 & 10 & 6 & 4 \\
SE & Santiago del Estero & 1 & 11 & 1 & 1 & 1 & 0 \\
TU & Tucuman & 6 & 65 & 5 & 5 & 4 & 1 \\
& & 120 & 1300 & 392 & 100 & 34 & 66 \\
\hline
\end{tabular}

Based on our evaluation of the available temperature data, it appears that climatic factors alone are not the only reason for limiting the range and distribution of Africanized bees (Fig. 2). The samples collected in Mendoza, Rio Negro and San Juan in riparian forest support this contention. Lack of adequate nesting sites, shortage of water and limited food sources in large areas in San Juan, Mendoza, and San Luis may be just as critical as weather conditions. Although the limiting factors are unknown, it is possible that some small populations of Africanized bees could maintain themselves near riparian habitats and irrigated agricultural areas and thus extend their range. Even though we found Africanized and European honey bees at an altitude of about $2000 \mathrm{~m}$ (Rodeo, San Juan), they were no longer present at a nearby valley separated by 20 or $30 \mathrm{~km}$ of desert and $500 \mathrm{~m}$ of altitude. Sмiтh $(1961,1973)$, however, collected $A$. m. adansonii from the sea level on the coast up to $3500 \mathrm{~m}$ in Ethiopia. Since the identity of many of our collected bees is presently unknown, a detailed description of the factors limiting the range of Africanized bees awaits the complete analysis of our honey bee samples.

At the start of our investigation, a transitional zone of mixed European and Africanized bee populations was expected along the southern limit of Africanization 


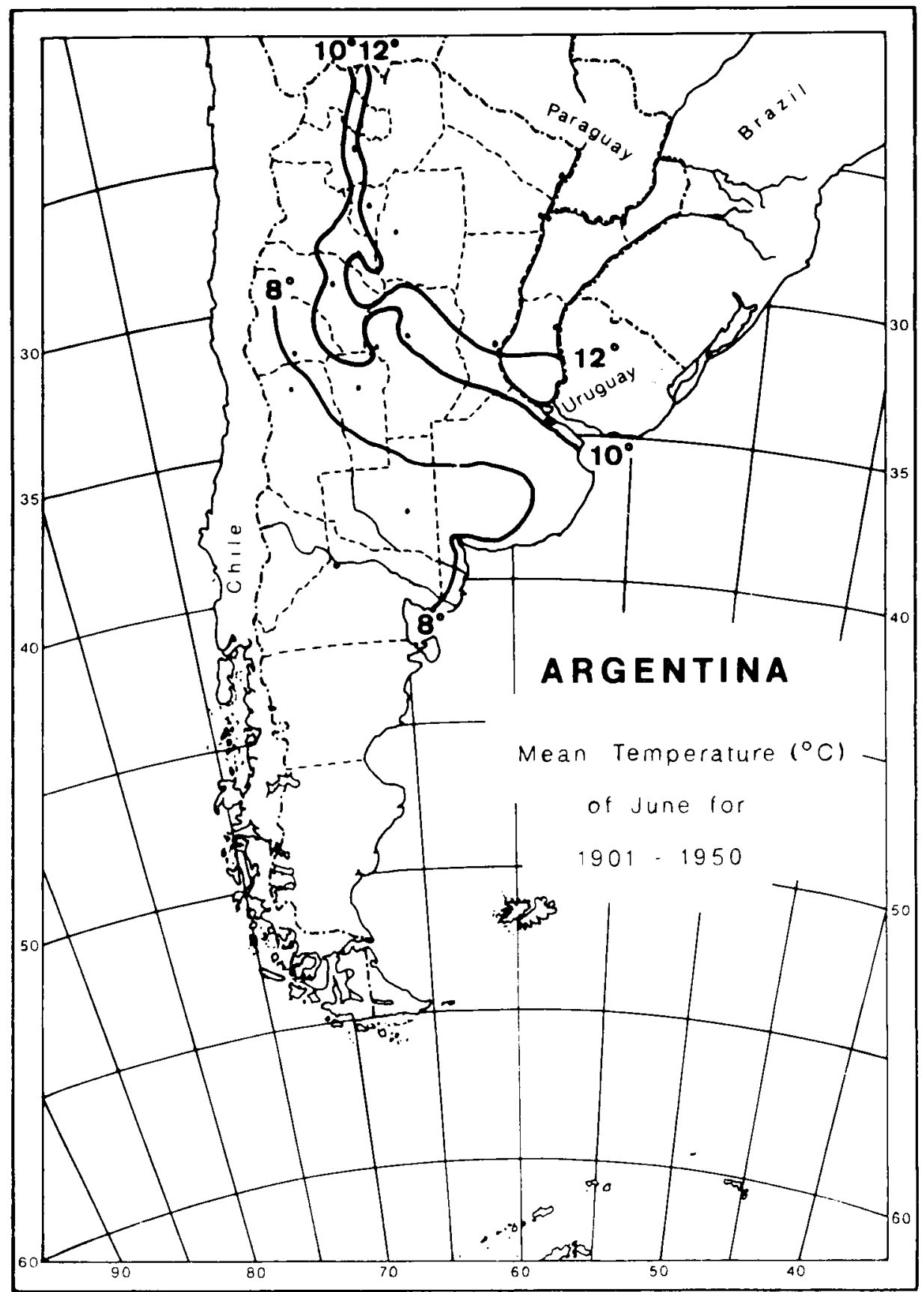

Fig. 2. - Mean temperature for June 1901-1950 (Similar mean temperature for July) 
(32 $\mathrm{S}$ to $34^{\circ} \mathrm{S}$ ) according to KERR et al. (1982) and TAYLOR (1977). Recently, TAYLOR and SPIVAK (1984) reported more extensively on the predicted distribution of Africanized bees in Argentina and the prospective limits of their distribution in the U.S. Because of the small number of morphometrically analyzed samples presently available, but the surprising finding of Africanized bees near the $39^{\circ} \mathrm{S}$ in Rio Negro, in Mendoza and near Rodeo, San Juan, a revision of the previously suggested distribution of Africanized bees for Argentina and the U.S. may be necessary. The results of our recently completed study on overwintering (KRELL et al., 1985), and additional studies still in progress, should shed more light on the factors limiting the distribution of Africanized bees in Argentina.

Received for publication in September 1984.

Accepted for publication in March 1985.

\section{ACKNOWLEDGEMENTS}

The authors would like to take this opportunity to express their gratitude to numerous apiculturists, government officials and colleagues for their helpful suggestions and assistance during the planning, training and travel periods. In particular we would like to thank Drs. Anita M. Collins and Thomas E. Rinderer, U.S.D.A., Baton Rouge, Louisiana for equipment and the time necessary to familiarize us with their defensive behavior test.. Drs. Lionel S. Goncalves and David De Jong, USP, Ribeirao Preto, Brazil, for the use of their facilities, vehicles and valuable suggestions prior to our departure for Argentina.

We are particularly grateful to Moises Katzenelson, INTA, 25 del Mayo, Argentina, for taking the time to travel with us and for introducing us to many of his associates and beekeeping friends. We would also like to acknowledge the excellent cooperation of the several hundred beekeepers contacted during our survey.

Thanks also go to several persons whose special talents and expertise helped to bring the study to its present status : Higinio Azcurra, Miguel D. Barrionuevo, Guillermo Becker, Luis Guillermo Cornejo, Dr. Luis De Santis, Hector Delle Ville, Laura and Carlos Enzenhofer, Pater J.V. Garcia Geniz, Julio F. Leitner, Margarita M. Minatta, Miguel Paulon, Eduardo R. Popolizio, Dr. Alfredo M. Rambaue, and Alfredo D. Rocha.

We also wish to thank Manuel Mejia, Irene Sauer, and Thomas Montgomery of the 1983 survey team as well as Jose Rodriguez and Jeff Pettis, members of our 1984 survey team. Without the help of these persons, and many more not mentioned, our research would not have been possible.

\section{RESUME}

\section{RECHERCHES PRELIMINAIRES SUR LA REPARTITION GEOGRAPHIQUE DES ABEILLES AFRICANISEES EN ARGENTINE}

On rappelle brièvement la route d'invasion des abeilles africanisées vers l'Argentine. On présente les résultats préliminaires d'une étude d'ensemble menée dans 17 provinces d'Argentine, de janvier 1983 à mai 1984. On a évalué, avec le test mis au point par Collins et KubaSEK (1982), le comportement de défense de 1300 colonies réparties dans 120 ruchers. Pour chaque colonie on 
a également recherché les parasites et les maladies, estimé la surface de couvain et la population d'abeilles et prélevé sur les rayons de couvain un échantillon de 30 à 60 abeilles pour analyse morphométrique. De plus, on a récolté, dans la mesure du possible tous les $50 \mathrm{~km}$ dans 9 provinces, des échantillons sur le bord des routes et des abeilles provenant de colonies sauvages (Tabl. 1). Environ $6 \%$ de tous les échantillons pris soit dans les colonies testées, soit sur le bord des routes, ont été identifiés du point de vue morphométrique. Le tableau 1 et la figure 1 donnent leur répartition géographique ainsi que celle de tous les échantillons non identifiés.

D'après notre évaluation des chiffres de température disponibles, il semble que les facteurs climatiques seuls ne constituent pas l'unique cause de limitation de l'extension et de la répartition géographique des abeilles africanisées (Fig. 2).

On a trouvé pour la première fois des abeilles africanisées en Mendoza, à I'altitude d'environ $2000 \mathrm{~m}$, près de Rodeo, San Juan. On a également récolté un échantillon composé de $60 \%$ d'abeilles africanisées et de $40 \%$ d'européennes dans une colonie près de Cinco Saltos, Rio Negro. La présence d'abeilles africanisées à la latitude proche de $39^{\circ} \mathrm{S}$ est à notre connaissance la plus méridionale connue.

Au début de notre recherche, on s'attendait à trouver une zone transitoire de populations européennes et africanisées mélangées le long de la limite sud de l'africanisation (32"S à 34S), d'après les rapports des autres chercheurs.

En raison de la surprenante découverte d'abeilles africanisées aux alentours du 39" degré de latitude sud dans le Rio Negro, le Mendoza et près de Rodeo, San Juan, il pourrait être nécessaire de réviser la distribution, admise jusqu'à présent, des abeilles africanisées en Argentine el aux Etats-Unis, en dépit du petit nombre d'échantillons actuellement analysés.

\title{
ZUSAMMENFASSUNG
}

\author{
VORLÄUFIGE ERGEBNISSE EINER UNTERSUCHUNG \\ DER VERBREITUNG AFRIKANISIERTER HONIGBIENEN IN ARGENTINIEN
}

Die Einwanderungswege der Afrikanisierten Bienen nach Argentinien werden kurz beschrieben. Dazu werden die vorläufigen Resultate einer Überprüfung vorgelegt, die zwischen Januar 1983 bis Mai 1984 in 17 Provinzen Argentiniens durchgeführt wurden. Insgesamt wurden auf 120 Bienenständen 1300 Bienenvölker mit dem Test auf Verteidigungsverhalten nach Collins und KuBasEK (1982) geprüft. Jedes Volk wurde auch auf Parasiten und Krankheiten untersucht. Volksstärke und Brutumfang wurden geschätzt und es wurden Proben von 30-60 Bienen von Brutwaben für die morphometrische Untersuchung entnommen. Zusätzlich wurden noch 392 Proben von Bienenvölkern entlang der Straße und von wildlebenden Völkern aus 9 Provinzen Argentiniens gesammelt, wenn möglich in Abständen von $50 \mathrm{~km}$ (Tab. 1). Ungefähr $6 \%$ der im Feldtest geprüften oder entlang der Straße gesammelten Proben wurden morphometrisch identifiziert. Ihre geographische Verteilung und die aller noch nicht bestimmten Proben sind in Tab. 1 und Abb. 1 eingezeichnet.

Nach unserer Auswertung der verfügbaren Temperaturdaten hat es den Anschein, daß klimatische Faktoren allein nicht der einzige Grund für die Begrenzung des Verbreitungsgebietes und der Verteilung der Afrikanisierten Bienen sind (Abb. 2).

Zum ersten Mal wurden Afrikanisierte Bienen in Mendoza und in einer Höhe von ungefähr $2000 \mathrm{~m}$ bei Rodeo, San Juan, gefunden. Ferner sammelten wir eine Probe mit $60 \%$ Afrikanisierten und $40 \%$ europäischen Bienen aus einem Volk nahe Cinco Saltos, Rio Negro. Unseres Wissens nach ist diese Fundstelle von Afrikanisierten Bienen nahe dem 39. Breitengrad $S$ dic südlichste Fundstelle, die bisher bekannt wurde.

Bei Beginn unserer Arbeiten wurde nach den Berichten anderer Untersucher eine Übergangszone von gemischten europäischen und Afrikanisierten Bienenpopulationen entlang der Südgrenze der 
Afrikanisierung $\left(32^{\circ}-34^{\circ} \mathrm{S}\right)$ erwartet. Auf Grund der überraschenden Funde Afrikanisierter Bienen in der Nähe des 39. Breitengrades in Rio Negro, in Mendoza und bei Rodeo, San Juan, könnte trotz der kleinen Zahl der bis heute untersuchten Proben eine Revision der früher angenommenen Verbreitungsmöglichkeit Afrikanisierter Bienen in Argentinien und in den USA nötig werden.

\section{REFERENCES CITED}

Collins A.M., Kubasek K.J., 1982. - Field test of honey bee (Hymenoptera, Apidae) colony defensive behavior. Ann. Entomol. Soc. Amer., 75, 385-387.

Collins A.M., Rinderer T.E., Harbo J.R. and Bolten A.B., 1982. - Colony defense by Africanized and European Honey Bees. Science, 218, 72-74.

DAlY H.V., BALling S.S., 1978. - Identification of Africanized honey bees in the western hemisphere by discriminate analysis. J. Kansas entomol. Soc., 51, 857-869.

De Santis L., Cornejo L.G., 1968. - La abeja africana Apis (Apis) adansonii en America del Sur. De la Revista de la Facultad de Agronomia. La Plata, 44, 17-35.

DiETz A., 1978. - An anatomical character suitable for separating drone honey bees of Apis mellifera ligustica from Apis mellifera adansonii. Proc. Int. Apimondia Symposium on Apiculture in Hot Climates. 102-106.

Dietz A., 1982. - Honey Bees. In : Hermann, H.R. ed., Social Insects, Academic Press, New York. Vol. 3, 323-360.

Goncalves L.S., 1984. - Comments on the aggressiveness of the Africanized bees in Brazil. Am. Bee J., 114, 448-449, 450.

Goncalves L.S., 1982. - The economic impact of the Africanized honey bee in South America. Proc. 9th Congr. of IUSSI., Bolder, Co : The Biology of social insects ed. M.D. Breed and H.E. Evans, 134-137.

Kempff Mercado N., 1973. - Development of apiculture in Bolivia. 24 Int. Beekeep. Congr. Buenos Aires (Argentina) : 65-66.

KERR W.E., 1967. - The history of the introduction of Africanized bees in Brazil. Apicult. in West. Australia, 2, 53-55; South Afric. Bee J., 39, 3-5.

KERR W.E., 1969. - Some aspects of the evolution of social bees (Apidae). In : T.C. Dobzhansky, M.K. Hecht, Wm. C. Steeve, eds., Evolutionary Biology, Appleton-Century-Crafts. New York, Vol. 3, 119-175.

Kerr W.E., Leon Del Rio S. de, Barrionuevo M.D., 1982. - The southern limits of the distribution of the Africanized honey bee in South America. Am. Bee J., 122, 196-198.

Krelt. R., Dietz A., Eischen F.A., 1985. - A preliminary study on winter survival of Africanized and European honey bees in Cordoba, Argentina. Apidologie, 16 (2), 109-118.

Michener C.D., 1975. - The Brazilian bee problem. Annu. Rev. Entomol., 20, 399-416.

Rinderer T.E., Sylvester H.A., 1981. - Identification of Africanized Bees. Am. Bee J., 121, 512-516.

Ruttner F, 1981. - On the taxonomy of honey bees of tropical Africa. Proc. 28th Int. Congr., Acapulco, Mexico, p. 278-287.

SмIтн F.G., 1961. - The races of honey bees in Africa. Bee World, 42, 255-260.

Smith F.G., 1973. - African races of Apis mellifera. Apiacta, 8, 99-101.

TAYlor O.R., 1977. - Past and possible future spread of Africanized honey bees in the Americas. Bee World, 58, 19-30.

TaYlor O.R., SPIVAK M., 1984. - Climatic limits of tropical African honey bees in the Americas. Bee World, 65, 38-47. 